\title{
Allegorical narratives: redefining the evolution of ornamented aesthetic principles of Langkasukan art of the Malay Peninsula, Malaysia
}

\author{
Sabariah Ahmad Khan
}

Faculty of Art and Design, University Technology MARA, West Malaysia

\begin{abstract}
The origin of the Malay motif of Langkasuka was believed to encrust in all forms of art objects as early as from the 2nd century AD. The Langkasukan ornamentation which embodies the surface articulation of artefacts enfolds the historical construction of its indigenous culture and ethnicity. With close embedded intention, the Langkasukan ornamentations signify the relationship and graphic expression based on national artistry, racial, creativity, technical skill and religious cultural properties. The Langkasukan motif, characterised by a spiral formulation derived from Hinduism-Buddhism is attributed through a process of modification and stylistic transformation by the artisans and craftsmen of the east coast of Malaysia. Through the web of influences from varied aesthetic sources generated through polity, migration, trade and commerce, a distinctive character in the composition of the patterns deem a rebirth of vernacular aesthetic principles contributing to an embracement of stylistic methodology, present to this day. The principles of Malay art decoded the hermeneutics adaptation and application.

The paper attempts to present an analytical study of 100 Malay artefacts ranging from weaponry, woodcarving, puppetry and illuminated manuscripts. The studies would narrate the descriptive nature of the hybrid patterns and manifestations of the early 1800 s, with the infusion of Islamic and the abstract norm of animism, Buddhist iconographic symbols overlapping with Hindu traditional motifs and a twist of local flavour. The analysis would reveal an even pattern of distribution of artistic ingenuity in terms of design, form and
\end{abstract}


compositional structure. The aesthetic details vary testimony to the artisans' altered innovation governed by function, status and ownership.

Keywords: Langkasuka, ornaments, arts, aesthetic.

\section{Introduction}

The existence of the northern Malay states was not obvious though evidence of the civilisation and richness in all art forms had rooted much earlier compared with the Malaccan Empire [1]. Rentse [2] acclaimed that in the early 1500s, the existence of Malacca and its dependencies was made known to the world by the Europeans who sailed to trade and colonise. Little was mentioned of the history of north east Malaya due to its isolated position. Malays of the north east states include Kelantan, Lankasuka the modern Malay Patani (see figure 1) and Ligor represent a group that is different in many aspects from the Malays in the west and south.

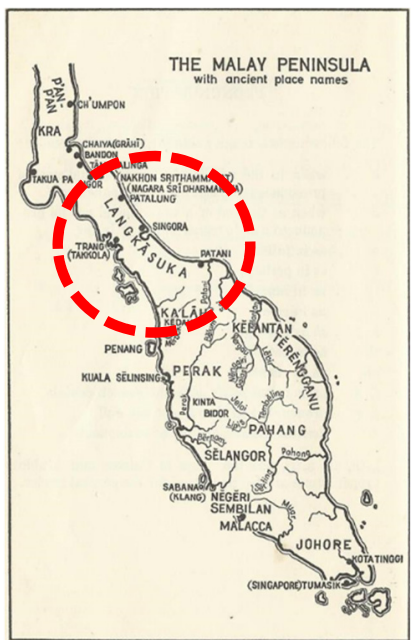

(a)

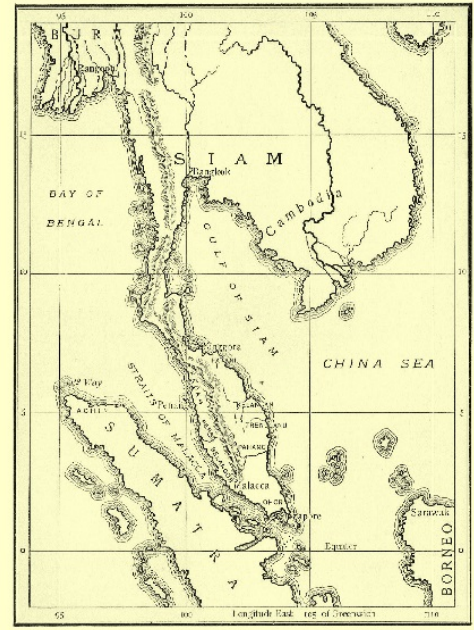

(b)

Figure 1: (a) Location map indicating the placement of the kingdom of Langkasuka (source: reconstruction map of ancient Malaya by Devahuti D., India and ancient Malaya: from the earliest times to circa A.D. 1400, Donald Moore Eastern Universities Press, Singapore 1965); (b) Map of Ancient Malay (source: http://elfinspell.com/FolkloreCollections/Skeat-FablesAndFolkTales/Notes.html).

The Malay traditional decorative art found today in the eastern region undeniably took its transformation from the Lankasuka model [3]. The classification on the distinctive characteristic of the ornamented patterns found were evidently established and formulated in three forms (figure 2). The first, known as the Lankasuka motif 'kelopak dewa' (godly petal), which was 
developed during the 6th century or even earlier, secondly, the old Malay motif, 'kelopak maya' which evolved from the Lankasuka motif, was renowned circa 1600 and thirdly, 'kelopak hidup' (Malay living leafed) motif, came into being in the 18th century. These rich elaborated embellishments were found especially on wood carved panels, grave makers, illuminated Quranic manuscript decorations and the Malay keris (dagger) hilt [4].

\section{Langkasukan motif}

'Daun Langkasuka' (Lankasuka leaf) or 'daun dewa'(God's leaf) motif (see figure 2) formed the basic structure that supports and is infused with combination of a variety of local flowers and leaves and other forms which are magnificently arranged in a profoundly stylistic manner. These are especially found in various applications in Malay art objects. The leaf shape motif mirrored in the shape of a finger gesture is evidently connected to the movement of the Malay martial art of self-defence - the silat or dance [4]. The shape could also possibly be connected to the influence of the Brahman-Buddhist mudra hand gesture or the abstraction of the Makara (see figure 3). It was customary for the artisans to determine appropriate plant or animal forms as inspirations and conceptualise these images for the function of the embellishments. Selected patterns were either repeatedly organised or incorporated in a symmetrical order,

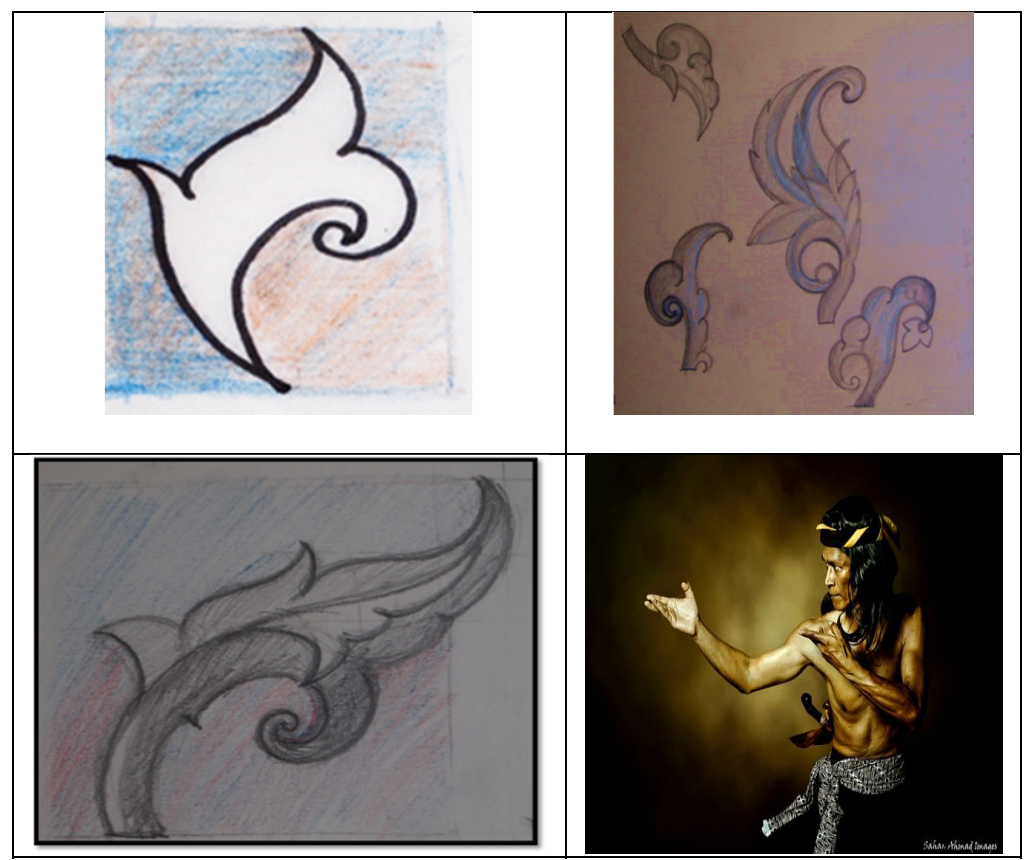

Figure 2: Researcher's drawing analysis of the abstracted Daun Langkasuka. Below right image of Malay Silat hand gesture, believed to influence the structural formation of the leaf motif. 


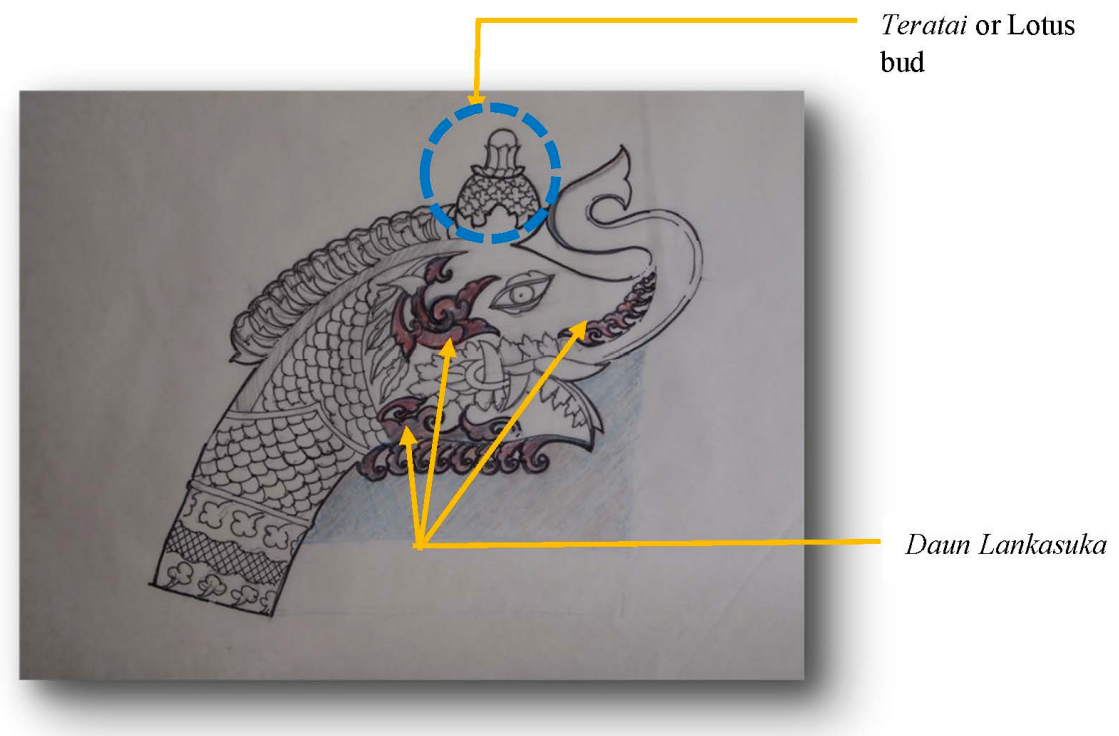

Figure 3: Illustration of Badek Makara hilt adorned with Langkasukan motifs. consummating the outline of Hindu symbols of either Stupa (Buah Gantung), Kala (guardian deity), Pohon Bodhi/Pohon Beringin (Tree of Life), Makara (Hindu mythological creature)/Salur Bayu, Gunungan (Mount Meru) and Teratai or Lotus that symbolised water and earth (see figure 4).



Figure 4: $\quad$ Illustration of Pohon Beringin (Tree of Life) in the shape of the lotus petal with the top pinnacle of the lotus bud. The Langkasuka motifs decorate the shape. The concept of the symbolical representation as presented by Norhaiza, a master Malay woodcarver from Terengganu. 
With the embracement of Islamic principles, the Hindu forms suspended into foliaged and abstract compositions. The arrangement of patterns are generally organised into an order of balanced and systematic organisation. Rosnawati Othman [4] formulates six principles of composition on the Malay dagger and wood carvings which she concludes with the concept of radiating from a source, depicting natural flow and growth of line work; a decoration that depicts nature and forms part of the construction and harmony in contrast.

\subsection{Aesthetics and the Malay Islamic aesthetic principles}

The word aesthetic or 'aesthetica' having derived from the Greek word aesthesis, is defined as any element that relates to beauty. Aesthetics are referred to the value of sensory perception and understanding or sensuous adoration towards subject of beauty $[5,6]$. Though the meaning of the word set different sublime of definitions by researchers of the modern world, it deals with the western philosophy of describing art for an example, as the beautiful as well as with reasoning standards of value judgment in the art and other aspects of human life and culture [7] on Lawal [8]. In the anthropological context, aesthetics directs to the relationship between art, attitudes and activities. Aesthetic encapsulates two meanings as, firstly, a set of principles concerned with the nature and appreciation and secondly as artistic taste [9].

The art or artefact in a pure sense are objects produced for the purpose of enduring the capacity to satisfy the aesthetic interest and under standard conditions provides the percipients aesthetic experiences [10]. Aesthetic in arts embodies symbols, language, meanings and method of interpretation, dependable on the intention of the artist for emotional reaction of the viewer.

Aesthetic principles would conferred to crafting objects of art with intention to please the senses, based on fundamental reasoning with sets of general rules and guidelines intended to support structured ideas and values through action and results.

Art forms of the Islamic Malays in Malaysia encapsulate the principles of beauty, function, materials in line with Islamic values. Craftsmen and artisans endured to different techniques in fabricating the products. Materials are selected based on the nature of appropriateness enhancing the purpose of beautification with skilful and artistic sensitivity of the individuals. Stylization may varies, foliage, geometric shapes and fauna are the choices for motifs and patternings. In the context of Islamic principles the stylization of motifs are denaturalized and abstracted with symbolic meanings with reference to Jamal (beauty) and Jalal (magnificent) [11].

The Malay concept of aesthetic principles (see figure 5), underpins five basic formulations. The principles, of Berhalus (finesse), Berguna (usefulness), Bersatu, (unity), Berlawan (contrast) and Berlambang (symbolic) [12].

Berhalus construe delicacy of object art and the chosen media. The inspirations are derived from nature characterising the formation of the artworkmaterial. The outcome of this execution defined the refinement of artistry. Examples are found on keris hilts such the Tajong and Coteng. 
The second principle Berguna, refers to the functionality of object in art. Objects created to serve the utilitarian purposes in lace with aesthetic attributes. Objects produce served a volume of purpose from wood cravings, architectural components, boat design, utensils, jewellery and others.

Bersatu, confers to the integration and unification between form and content in the visual arts. Application of this principle enables the composition to be communicated and narrated clearly.

The fourth principle Berlawan necessitated the elements of harmonious contrast. Two opposites complementing the other, conceding for flexibility, harmony and balance in design. Employment of materials, contrasting colours, shapes, textual effect emphasizes and ennobles the aesthetic qualities of the art.

Berlambang the fifth principle associate to symbolic connotations embedded in the art. The content in the form such as in wood carving, wayang kulit (puppetry) and architecture reveals symbolic meaning to history, culture and archetypal beliefs.

The philosophical embodiment of aesthetic intention dictates the manifestation level of the artist's creativity and mastery. To the Muslim artists, the visual imageries are expression to the act of devotion for Allah, the Creator of the universe, for He is beautiful and who loves beauty [13].

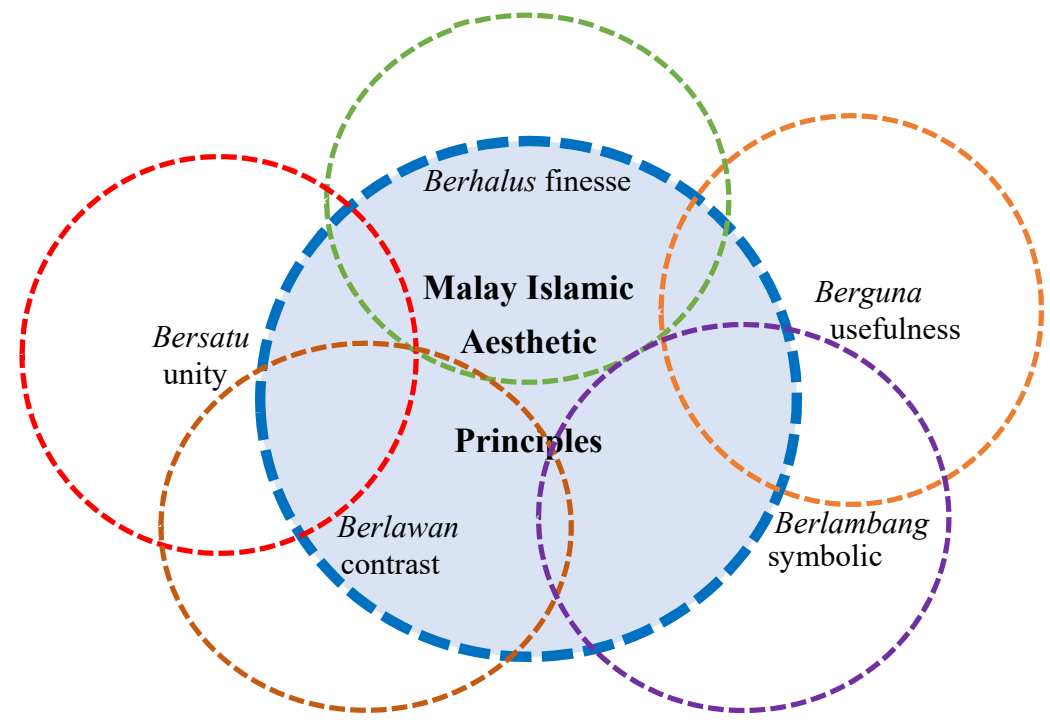

Figure 5: Malay Islamic aesthetic principles: Zakaria Ali, Thoughts on the aesthetics of Malay Artefacts, Wacana Seni, Journal of Arts Discourse, Ji., Vol. 5, 2006.

\subsection{Relationship with visual elements, motifs and ornaments in Malay art objects}

The word 'ornament' is described in the Oxford dictionary as an object designed to adorn something or a decorative item as a whole. Architecture for example is a 
physical and visual representation of a race. It narrates the thoughts of man as the architect for his dwelling, who adopts ornaments as accessorial features [14]. Cockerell defines ornamentation as a 'vehicle of architectural expression' [15]. Ornamentation on architecture and the arts are narrations intended as functional devices of a society. Ornamentations are identified to suggest being decorative emblems serving an allegorical significance with stories or fables that direct the eye for concentration towards sensational delight and are a collective expression of the artistic mind. Purely addressing the society of a particular period of time [16].

In a contemporary context, ornaments universally are material support embellishments defined by trends, design directions and as experimental forays. The popularity of ornamentations associated with decorative intention showcase creativity and craftsmanship of artistic works [17].

Ornamentation visually constitutes as parts or as a whole in the composition of art forms. Ornamentations, motifs and visual elements applied to art are interconnected to function on the object or product. The interconnectivity as in the Malay arts can be illustrated as in figure 6 .

\section{Research findings}

A qualitative method was used as a tool to examine and analyse the subject of study. The researcher additionally attempts to formulate building a theory through an explorative and interpretive research design strategy as to conclude and allow for a clear understanding of the ornamented patterns used by local artisans. Both methods are significant for data gathering from these two sources.

Data was gathered through analysing illustrated documents, reflective observations and evaluations from structured and open-ended interviews. The interviews were carried out on twenty present informant wood carvers, puppet makers, Quranic illuminators and keris hilt carvers from Kelantan and Patani. The intention is to make comparative analysis on the ideation and to seek current modes of practice used.

The analysis reveals that Malay traditional art objects especially the wood carvings, keris Tanjong and Coteng have retained their consistency in the ways symbols, motifs, compositions, patterning and arrangement are narrated. The language of meanings, codes of rules of interpretation remain as intended by the artists to the patrons. The evolution is a cycle based on the initial practice of the ancient masters to their current successors.

In this era, the elements and aesthetic principals embedded into the art forms such as in textiles, jewellery contained a less symbolical relationship. The intention of the artisans and artists was purely aesthetics for the commercial market. The innovators highlight the value of heritage, soul, custom, culture, race, belief, practice and ownership. The techniques employed, functionality and material usage depend on the skills, mastery, experiences and knowledge of the artisans and craftsmen. The Langkasukan motif, although stylised into simpler imageries are determined by the craftsmen and artists who remain as the initiators, deciding on the complexity of visual making. 


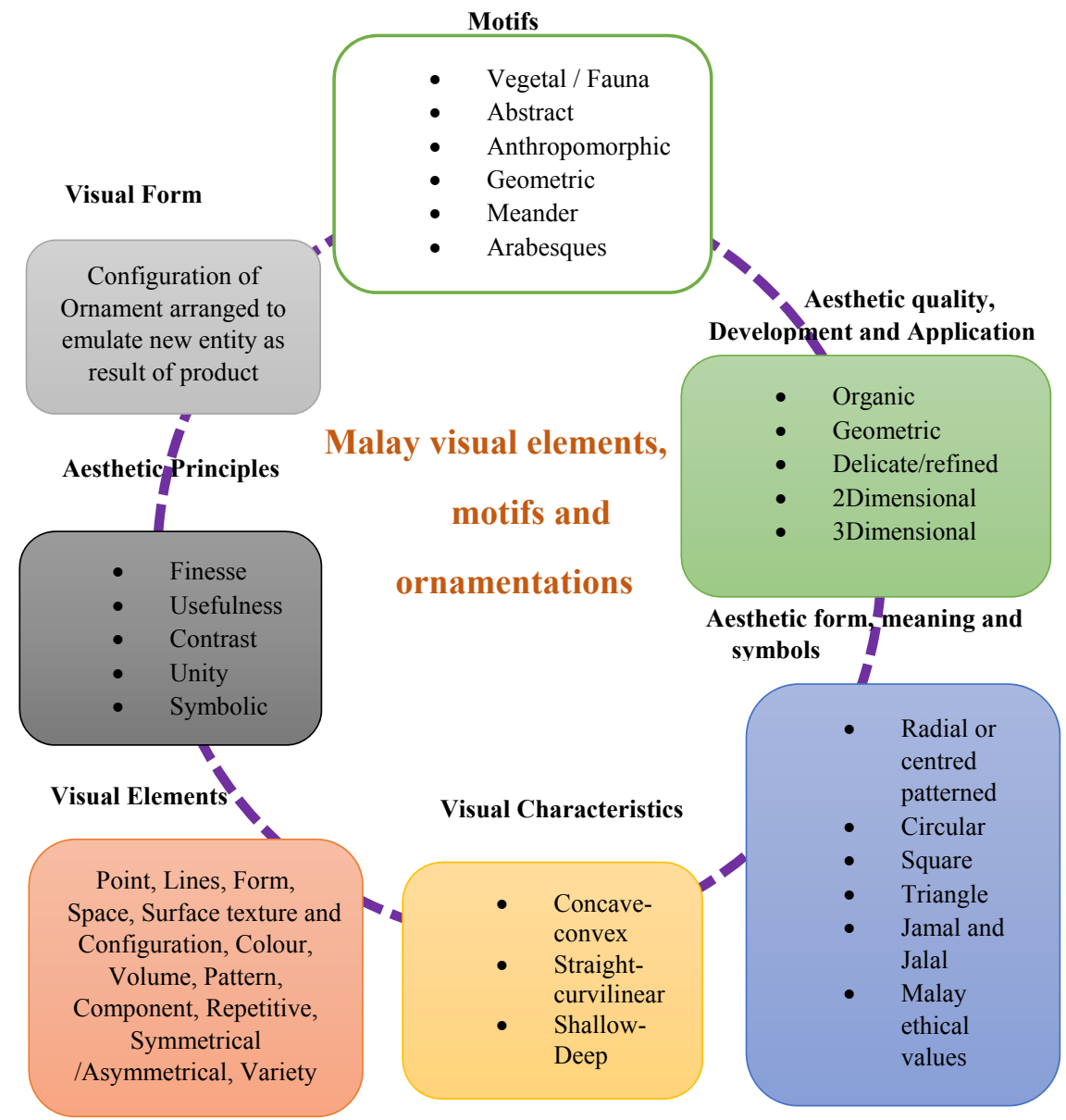

Figure 6: Relationship of visual elements, motifs and ornaments of Malay Islamic art objects (source: Sabariah Ahmad Khan).

\section{Conclusion}

The art motif of Langkasuka clearly reflects the identity and culture of the ancient Malay Kingdom of Langkasuka. Wood carvings, metallurgy, puppetry, illuminated Ouranic manuscript art of the aristocrats, were adopted from the integration and incorporation of Pre-Hindu-Buddhist artistic traditions with Islamic patterns as symbols of heavenly gardens. The concept of the Malay aesthetic remains a strong character to reflect the Malay cultural traits, custom and racial identity of the Malays of the Malaysian peninsula. In particular, woodcarving and the Keris hilts have attained their attributes and characteristics as mediums of deciphering a language through imprinting symbols of man, his Creator and his acknowledgement of Allah the maker of the universe. 


\section{References}

[1] Sheppard, M., Malay Arts \& Crafts, M.B.R.AS Reprints, Kuala Lumpur: Malaysian Branch of Royal Asiatic Society, 2011.

[2] Rentse, A., A Historical Note of the North-eastern Malay states, Journal of the Malayan Branch of the Royal Asiatic Society, Vol. 20, No: 1, (141) pp. 23-40, 1947.

[3] Noor, F. \& E. Khoo, Spirit of Wood: The Art of Malay Woodcarving, Periplus, 2003.

[4] Rosnawati Othman, The Language of the Langkasukan Motif, Indonesia and The Malay World Vol. 33, No: 96, 2005, pp. 97-111.

[5] Hekkert, P., Design Aesthetics: Principles of Pleasure in Design, Psychology Science, Vol. 48, pp. 157-172, 2006.

[6] Harrington, A., Art \& Sociology Theory: Sociological Arguments in Aesthetics, Chapter 2, p. 32, John Wiley, New York, 2004.

[7] Van Damme, W., Some Notes on Defining Aesthetics in the Anthropological Literature, JASO 22/2, pp. 167-181, 1991.

[8] Lawal, Hameed Olutoba, Cultural Aesthetics in Nigerian Video Films. http://www.sonta.nico.gov.ng/index.php/papers/304-lawal-hameedolutoba-

[9] Young Cho, Schwarz, The Handbook of Interior Design, Thompson, JA, Blossom, NH (eds.) Chapter 29, Wiley \& Blackwell, N. York, 2015.

[10] Beardsley's Aesthetics http://www.plato.standford.ed/entries/bearsdleyaesthetics

[11] Abdullah bin Mohamed, Islam Sebagai Teras Falsafah Keindahan Melayu dengan Tumpuan Khas kepada Seni Bina dan Seni Ukir di Kelantan, Monograf Perbadanan Muzium Negeri Kelantan; Warisan Kelantan XXV. pp. 39-41. Kuala Lumpur: United Selangor Press Sdn Bhd. Malaysia, 2006.

[12] Zakaria Ali, Thoughts on the aesthetics of Malay Artefacts, Wacana Seni Journal of Arts Discourse, Ji., Vol. 5, 2006.

[13] Syed Ahmad Jamal, Rupa dan Jiwa First Edition, Dewan Bahasa dan Pustaka, Kemeterian Pendidikan Malaysia, 1992.

[14] Jones, O., The Grammar of Ornament, Deutsch Press, 2010.

[15] Bordelau, A., Charles Robert Cockerell, Architects in Time, Reflections Around Anachronistic drawings, Ashgate Publishing, Ltd, England, pp. 127-129, 2014.

[16] Dresser, C., Language of Ornament; Style of Decorative Arts, Reprint Edition, Gramercy, 2003.

[17] Mitrache, A., Ornamental Art \& Architecture: Decoration, ProcediaSocial \& Behaviour Sciences, Vol. 51, The World Conference on Design, Arts \& Education (DAE) Antalya, Turkey, pp. 567-576, 2012. 